\title{
Assessment of Arsenic Exposure to Human, Concentrations in Tube Well Water and Urine, and Body Mass Index
}

\author{
M. Mizanur Rahman Sarker
}

\begin{abstract}
Arsenic in drinking water is a major public health concern in Bangladesh, affecting several millions of people who live in rural areas, because of insufficient financial resources and public health infrastructure and lack of awareness. The present study empirically analyzes the arsenic exposure to human, arsenic concentration in urine and tube well water and body mass index of sample respondents of a population survey. A five-stage sampling procedure was undertaken for the selecting the 418 sample respondents for examining the arsenic concentration in urine and body mass index and 86 sample tube well for testing the arsenic concentration in drinking water. It was found that the sample respondents had an average body mass index of 19.52 while the BMI of the sample respondents varied from 14.06 to 33.4 with standard deviation 3.02 which was represent the broad characteristics of BMI of rural residents. The average level of arsenic concentration in the drinking water was $285.37 \pm 193.13 \mu \mathrm{g} / \mathrm{L}$ with the ranging from 0 to $715.63 \mu \mathrm{g} / \mathrm{L}$. The mean arsenic concentration in the urine of the sample respondents was $637.85 \pm 478.69 \mu \mathrm{g} / \mathrm{L}$ creatinine. The concentration levels varied from $93.03-3198.00 \mu \mathrm{g} / \mathrm{L}$ creatinine. Melanosis in the palm, sole and trunk were the common signs in the patients. The present study shows that the highest amount of skin lesion was melanosis in palm (43.74\%) and the second highest in trunk (37.49\%). This study found high arsenic concentration in urine and drinking water and low body mass index.
\end{abstract}

Index Terms-Assessment, body mass index, exposure, human health, urinary arsenic.

\section{INTRODUCTION}

Exposure of arsenic from drinking water has been a major public health threat to millions of people in different parts in the world. Bangladesh is facing an increasing threat of arsenic contamination in groundwater which is associated with risk of skin cancer, cardiovascular, black foot disease, hypertension, adverse reproductive - outcomes, neurological disorder [1], [2] as well as other social and psychological problems[3]. In attempting to eliminate water-borne diseases caused by drinking contaminated surface water, millions of shallow wells were drilled in Bangladesh during the last 30

Manuscript received December 3, 2010. The author would like to thank the Japanese Government for a scholarship (Monbukagakusho) to allow the research.

Institute of Economic Research, Graduate School of Economics, Hitotsubashi University, 2-1 Naka, Kunitachi, Tokyo 186-8603, Japan (phone: 81-90-6654-9922; e-mail: mrs_bd@yahoo.com). years that brought geological arsenic to the surface. This caused an estimated 40 million people in this country suffering from arsenic poisoning-related diseases [4]. It is a very crucial issue for sustainable public health of Bangladesh, and some systematic investigations have been undertaken to assess the health burden. Typically, epidemiologic studies have relied on a few measures of arsenic (As) in drinking water to estimate exposure. The historical consistency of arsenic concentration is of particular concern with shallow ground water, which might be subject to greater fluctuation than water from a deeper well [5].

The study conducted within highly contaminated areas has found that $17-35 \%$ of the populations examined have skin lesions, and up to $3.4 \%$ of them have gangrene and ulcers [6]. Drinking water in Bangladesh contains mostly inorganic arsenic. Inorganic arsenic, once ingested is excreted through urine in human [7]. Inorganic arsenic is a naturally occurring toxicant and carcinogen [8], [9] that contaminates groundwater supply systems in countries around the world [10]. Flour and rice also contain inorganic arsenic, particularly if grown or cooked in areas with arsenic contamination in soil and water [11]. The metabolism of inorganic arsenic in the human body results in methylarsonate (MA) and dimethylarsinate (DMA), which are excreted in urine together with unchanged inorganic arsenic [12], [13]. A series of reduction and oxidation methylation reactions occur in liver to form monomethylarsonic acid (MMA) and dimethylarsinic acid (DMA) [14]. Approximately one-third of the hand tube wells in Bangladesh contain arsenic more than $10 \mu \mathrm{g} / \mathrm{L}$, the recommended level of arsenic in drinking water by the WHO [15].

Some studies have indicated that poor nutritional status may increase the risk of arsenic related health effects [16][21]. The respondents with below standard body weight for their age and sex were reported to have an overall 1.6 fold-increase in the prevalence of keratoses in West Bengal, India [18]. However, there are uncertainties about the relationship between exposure to As and its clearance in urine as a marker of exposure to As in drinking water. Improved estimates of exposure to As may be obtained by quantization of the amount of arsenic in the urine. In particular, there is limited information on the arsenic concentration in the urine and nutritional status. Moreover, accurate estimation of magnitude and pattern of exposure is critical for a better understanding of the adverse effects of chronic exposure to human body. Therefore, the objectives of 
this study are to conduct an initial assessment of sevearity and to identfy the pathway of arsenic exposure to human body, to investigate the arsenic concentrations in the drinking water and urine and association between arsenic concentrations in urine and body mass index.

\section{Methodology}

\section{A. Survey Area}

The study area of this investigation is southern region of Bangladesh. Two Upazilas namely Matlab South and Hajigong were selected from out of eight Upazilas of Chandpur district as it is known to be highly contaminated with arsenic in the underground water. The British Geological Survey [15] reported that there is high prevalence of arsenic in tube well water in Chandpur district. The upazila is the second lowest tier of administrative government in Bangladesh. The districts of Bangladesh are divided into sub-districts called Upazilas.

\section{B. Selection of Survey Sample}

A five-stage sampling procedure was undertaken. Firstly, two upazilas of Chandpur were selected purposively. Secondly, preliminary information on the severity of arsenic exposure to human was collected from the local NGOs personnel, health workers, and ICDDR, B field workers. Thirdly, thirty villages were listed on the basis of the severity of arsenic exposure. Fourthly, four villages (two + two) were selected randomly from two upazilas for the present study. Finally, 450 respondents were selected randomly.

\section{Survey Instruments}

The purpose of the study was described to the respondents and the issue of ethical consent was addressed by informed individual oral consent. A pre-design questionnaire was used to collect the very basic information like age, sex etc. as well as details information about arsenicosis problems if any respondent has arsenicosis problem(s). Four (two men and two women) interviewers were hired based on educational qualification and previous field experience. These four interviewers were thoroughly trained and used for pretesting the questionnaires and finally, they conducted the survey by face-to-face interview. Height was measured in centimeters and weight was measured in kilograms. Standing height and weight of each participant were measured with the subjects wearing light clothes and not wearing shoes. Total 418 urine samples were collected from respondents for arsenic concentrations test. Thirty two observations were excluded for non-response and refusal of participants. Participation was voluntary and data protection was observed throughout the study. In total 86 water samples were collected from tube wells for examining the arsenic concentration in drinking water.

\section{Assessment of Arsenic Exposure}

The total arsenic (As) concentrations of the water $(\mathrm{n}=86)$ and urine $(\mathrm{n}=418)$ were determined by an atomic absorption spectrometer equipped with a flow injection hydride generator (HG-AAS) and the part of the samples were also measured with inductively coupled plasma mass spectroscopy (ICP-MS) for cross cheek. Assay accuracy was ensured by inclusion of reference materials: NIST 1640 (trace metal in water; National Institute of Standards and Technology, Gaithersburg, MD, USA), and NIES 18 (Human urine, National Institute of Environmental studies, Tsukuba, Japan). All the measurements were within the certified ranges. Creatinine concentration in urine samples was determined with UV-VIS Spectrophotometric analyzer at $520 \mathrm{~nm}$ using a commercial creatinine kit, based on the Jaffe reaction.

\section{E. Statistical Analysis}

This study was used descriptive statistics to describe the data. All analyses were performed by using SPSS package. Descriptive analysis involved calculations of standard deviation, frequency distribution, percentage, mean and tabular statistics for reporting the skin lesion, arsenic concentrations in tube well and urine and body mass index.

\section{RESULTS AND DISCUSSION}

\section{A. Characteristics of Survey Sample}

The basic characteristics of survey sample include age, sex, height, weight, body mass index, arsenic concentration in tubewell and urine. The body mass index (BMI) of the respondents was categorized into four different classes, namely underweight (<18.50), normal weight (18.50-24.99), overweight (25-29.99) and obesity ( $\geq 30)$. The descriptive statistics of the sample characteristics are shown in Table 1. Of the total 418 respondents enrolled in this study, there were 163 male respondents and 255 female respondents with the age of maximum 86 years, minimum 14 years and standard deviation 15.67. The age range of males was 16 to 86 years with standard deviation 16.92; while that of females was 80 to 14 years with standard deviation 14.80 . The whole sample average height was $153.86 \mathrm{~cm}$ with the ranging from 131.0 to $177.4 \mathrm{~cm}$ and standard deviation 8.48 and weight was 46.30 $\mathrm{kg}$ with the ranging from $28.2 \mathrm{~kg}$ to $78.3 \mathrm{~kg}$ and standard deviation 8.41.

It was found that the sample respondents had an average body mass index of 19.52 while the BMI of the sample respondents varied from 14.06 to 33.4 with standard deviation 3.02. The normal weight respondents had an average BMI of 20.65 (range: 18.52 - 24.99), while the underweight respondents had 17.12 (range: $14.06-18.49$ ), overweight respondents had 26.00 (range: $24.52-28.33$ ), obesity respondents had 32.05 (range: $30.93-33.40$ ). The average level of arsenic concentration in the drinking water was $285.37 \pm 193.13 \mu \mathrm{g} / \mathrm{L}$ with the ranging from 0 to 715.63 $\mu \mathrm{g} / \mathrm{L}$. The mean arsenic concentration in the urine of the sample respondents was $637.85 \pm 478.69 \mu \mathrm{g} / \mathrm{g}$. The concentration levels varied from $93.03-3198.00 \mu \mathrm{g} / \mathrm{g}$.

\section{B. Skin Lesion of Sampled Arsenicosis Patients}

The distribution of skin lesion of surveyed arsenicosis patients is reported in Table 2. The present study shows that the highest amount of skin lesion was melanosis in palm $(43.74 \%)$ and the second highest in trunk (37.49\%). Leucomelanosis of arsenicosis patients was found at $2.08 \%$ in left palm, $10.41 \%$ in both palms, $6.25 \% \%$ in right and $8.33 \%$ both soles, $4.16 \%$ in back trunk and $10.41 \%$ in both front and back trunk. Among the arsenicosis patients, 
keratosis was found in both left and right palm of $4.16 \%$ of patients and in dorsum of hand and foot of $2.08 \%$ of patients. Around four percent of the respondents reported incidence of hyperkeratosis in sole and dorsum of hand and foot.

The melanosis, leucomalanosis and keratosis symptoms were identified around $11 \%, 2 \%$ and $2 \%$ of the respondents, respectively in the Hajiganj [22]. The present study was found that melanosis in palm, sole and trunk and keratosis in the dorsum of hand \& feet were the commonest signs in the patients. These findings are in agreement with other studies. The bodily marks of arsenicosis/arsenic poisoning are associated in the early stages with the palms of the hands and the soles of the feet. These stigmata are black patches known in Bengali as zengoo. At first blisters (foskaa), sores (ghaa), or gotta/goottee (swellings) develop on palms and soles and there is chulkani (itching). These goottee gradually turn into zengoo, which develop slowly. Later the skin becomes dark and spotted due to the deposition of a black pigment. Eventually the spots become thickened (mota) and hard (shokto), the worst prognosis being a cancerous gangrene [6], [23]. A similar finding was reported at Hajiganj Upzila of Chandpur district [24]. A recent study conducted within highly contaminated areas had found that $17-35 \%$ of the populations examined have skin lesions and up to $3.4 \%$ of them have gangrene and ulcers [6]. Skin lesions were the most common and prime manifestation of arsenic toxicity that had been considered as definite exposure [25]- [27].

\section{Pathway of Arsenic}

Arsenic, a toxicant of natural occurrence in mineral deposits, is used in many human activities such as manufacturing, agriculture, and medicine [28]. Arsenical compounds are transported into the environment mainly by water from wells drilled into the arsenic-rich geologic strata or by ambient air during smelting and burning of coal [28] [29]. The main route of arsenic exposure for the general population is via drinking water. The pathway of the arsenic exposure to human body is shown in the Fig. 1 on the basis of [30]. Arsenite and arsenate are the most common forms of arsenic in groundwater, as well as the most toxic of the four compounds. The pathway they follow through the human body is incredibly important to understanding arsenicosis, the disease caused by chronic arsenic poisoning. Fig. 1 shows how the human body is exposed to arsenic from different sources. There are three main ways in which arsenic poses a health threat to humans: (1) ingestion through drinking water (including water used for cooking); (2) consumption of food containing arsenic; and (3) breathing of arsenic brought into the air through burning of fuel contaminated with arsenic (e.g. straw or cow dung). Arsenic is not readily absorbed through skin so physical contact with contaminated water, for bathing and washing, is not toxic [30].

When arsenite and arsenate enter the human body, they bind to tissues, inhibit enzyme activity, and interfere with cell respiration.

TABLE 1: SOME BASIC CHARACTERISTICS OF THE SAMPLE RESPONDENTS

\begin{tabular}{lllll}
\hline Characteristics & Maximum & Minimum & Mean & Standard deviation \\
\hline Age $($ years) & 86 & 14 & 36.02 & 15.67 \\
Male & 86 & 16 & 37.18 & 16.92 \\
Female & 80 & 14 & 35.27 & 14.80 \\
\hline Height $(\mathrm{cm})$ & 177.4 & 131.0 & 153.86 & 8.48 \\
\hline Weight $($ kilogram) & 78.3 & 28.2 & 46.30 & 8.41 \\
\hline Body Mass Index $(\mathrm{BMI})$ & 33.4 & 14.06 & 19.52 & 3.02 \\
Underweight $=<18.5$ & 18.49 & 14.06 & 17.12 & 1.14 \\
Normal weight $=18.5-24.9$ & 24.99 & 18.52 & 20.65 & 1.69 \\
Overweight $=25-29.9$ & 28.33 & 24.52 & 26.00 & 1.11 \\
Obesity $=$ BMI of 30 or greater & 33.40 & 30.93 & 32.05 & 1.27 \\
\hline Arsenic concentration in tube well $(\mu \mathrm{g} / \mathrm{L})$ & 715.63 & 0 & 285.37 & 193.13 \\
\hline Arsenic concentration in urine $(\mu \mathrm{g} / \mathrm{g})$ & 3198.00 & 93.03 & 637.85 & 478.69 \\
\hline
\end{tabular}

TABLE 2: INFORMATION ON SKIN LESION OF SAMPLED ARSENICOSIS PATIENTS

\begin{tabular}{|c|c|c|c|c|}
\hline Type of lesion & Palm & Sole & Dorsum of Hand \& Foot & Trunk \\
\hline Melanosis & & & \multirow{4}{*}{---} & \\
\hline Left & $6(12.50 \%)$ & $1(2.08 \%)$ & & Front- $4(8.33 \%)$ \\
\hline Right & $5(10.41 \%)$ & $1(2.08 \%)$ & & Back-2 (4.16\%) \\
\hline Both & $21(43.74 \%)$ & $16(33.33 \%)$ & & Both-63 (37.49\%) \\
\hline \multicolumn{5}{|l|}{ Leucomelanosis } \\
\hline Left & $1(2.08 \%)$ & --- & \multirow[t]{3}{*}{---} & \multirow{3}{*}{$\begin{array}{l}\text { Front- - } \\
\text { Back-2 }(4.16 \%) \\
\text { Both- } 5(10.41 \%)\end{array}$} \\
\hline Right & --- & $3(6.25 \%)$ & & \\
\hline Both & $5(10.41 \%)$ & $4(8.33 \%)$ & & \\
\hline Keratosis & & & \multirow{2}{*}{$\begin{array}{l}\text { Yes-1 }(2.08 \%) \\
\text { No-47 }(97.92 \%)\end{array}$} & \multirow[t]{2}{*}{---} \\
\hline Left \& Right & $2(4.16 \%)$ & --- & & \\
\hline Hyperkeratosis & & & \multirow{2}{*}{$\begin{array}{l}\text { Yes-1 }(2.08 \%) \\
\text { No-47 }(97.92 \%)\end{array}$} & \multirow[t]{2}{*}{--- } \\
\hline Left \& Right & --- & $1(2.08 \%)$ & & \\
\hline
\end{tabular}




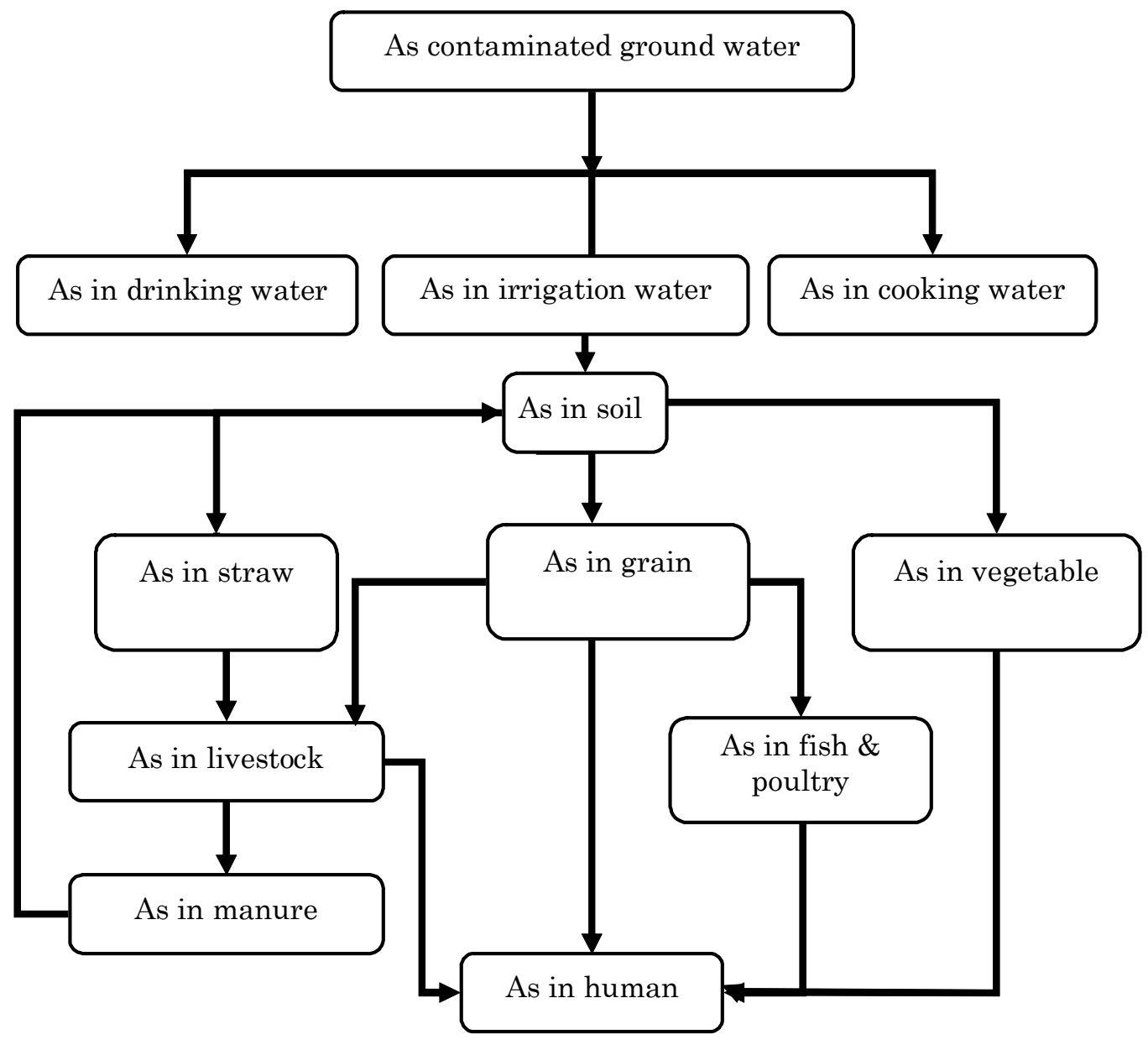

Fig. 1. Pathway of the arsenic exposure to human

In order to reduce the detrimental effects of these compounds, the body uses a detoxifying methylation mechanism to convert arsenite and arsenate to inorganic MMA and DMA. However, during the conversion of inorganic species to organic species, an extremely toxic intermediary compound, MMA is formed. Many scientists are currently studying this compound since it may add significantly to the overall carcinogenicity of inorganic arsenic. Once inorganic forms have been converted to MMA and DMA, they are excreted from the body. Thus, the presence of DMA and MMA in the urine, skin, hair, and nails is often evidence of arsenic poisoning. Urinary arsenic content best indicates recent exposure to arsenic since arsenic appears in the urine within two to eight hours and disappears within seven days. Arsenic content in the skin, hair and nails is more useful for measuring long-term exposure to arsenic.

\section{Assessment of Arsenic in the Tube Well Water Sample}

The distribution of the assessment results of the arsenic concentration in the tube well water are presented in Table 3. It was found that a total of $8(9 \%)$ tube wells water were contained less than $50 \mu \mathrm{g} / \mathrm{L}$ (maximum allowable limit in drinking water in Bangladesh) of arsenic which was within the national standard. On the other hand, 78 (91\%) tube wells water were contained more than $50 \mu \mathrm{g} / \mathrm{L}$ of arsenic, while 47 $(55 \%)$ were contained from greater than $50 \mu \mathrm{g} / \mathrm{L}$ to $500 \mu \mathrm{g} / \mathrm{L}$ and $31(36 \%)$ were contained greater than $500 \mu \mathrm{g} / \mathrm{L}$. The present study shows that the percentage of arsenic concentration more than $50 \mu \mathrm{g} / \mathrm{L}$ was higher than other studies. The finding of the current study is comparable with what has been reported in other studies. Previous studies reported that among the country's 7-11 million hand-pumped tube wells, approximately half have been estimated to supply groundwater with an As concentration $>50 \mu \mathrm{g} / \mathrm{L}$ [31], [32]. Approximately $53 \%$ of residents in the study area drank water with an As concentration $>50 \mu \mathrm{g} / \mathrm{L}$ [33]. The percentage of wells with an As concentration $>50 \mu \mathrm{g} / \mathrm{L}$ in other studies ranged from $30 \%$ [34] to 59\% [35]; the percentage $>300 \mu \mathrm{g} / \mathrm{L}$ ranged from $8.4 \%$ [36] to $20 \%$ [35]. A water quality survey by Bangladesh Bureau of Statistics and UNICEF has found that $12.6 \%$ of drinking water samples collected from 13,423 households around the country do not meet the Bangladesh drinking water standard for arsenic [30].

TABLE 3: DISTRIBUTION OF ARSENIC CONCENTRATION IN THE TUBE WELL WATER

\begin{tabular}{|l|l|l|}
\hline Arsenic concentration $(\mu \mathrm{g} / \mathrm{L})$ & $\begin{array}{l}\text { Number of tube } \\
\text { well }\end{array}$ & Percentage \\
\hline$\leq 50$ & 8 & 9 \\
\hline$>50-500$ & 47 & 55 \\
\hline$>500$ & 31 & 36 \\
\hline Total & 86 & 100 \\
\hline
\end{tabular}

\section{E. Assessment of Arsenic Concentration in Urine Sample}

Urinary arsenic (UAs) concentration are used frequently in epidemiological and environmental health studies as means of assessing exposure to As. Symptoms of arsenic poisoning include abnormalities of the urinary tract and digestive system, swelling of facial tissues, hair loss, changes in skin 
texture and color and several types of cancer. While short-term, high level dosages are instantly toxic, most cases of long-term exposure are difficult to detect and diagnose, since the symptoms appear over years and can be mistaken for other diseases. The urine arsenic level is often the preferred method, since it provides more accurate results. The results of arsenic concentration test in urine are presented in the Table 4 . The arsenic concentration in the urine sample of the $45(11 \%)$ respondents contained smaller than or equal to $200 \mu \mathrm{g} / \mathrm{g}, 174(41 \%)$ respondents contained from greater than 200 to $500 \mu \mathrm{g} / \mathrm{g}, 125(30 \%)$ respondents contained greater than 500 to $1000 \mu \mathrm{g} / \mathrm{g}$ and $74(18 \%)$ respondents contained greater than $1000 \mu \mathrm{g} / \mathrm{L}$. Average UAs concentration of the present study was higher than the other studies, such as 16 to $2746 \mu \mathrm{g} / \mathrm{g}$ [37] and smaller than 11 to $4144 \mu \mathrm{g} / \mathrm{g}$ [38]. The other study reported that the mean arsenic concentrations in the drinking water for the exposed and unexposed (control) population were $218.1 \mu \mathrm{g} / \mathrm{L}$ and $11.3 \mu \mathrm{g} / \mathrm{L}$, respectively [39].

TABLE 4: DISTRIBUTION OF ARSENIC CONCENTRATION IN URINE

\begin{tabular}{|l|l|l|}
\hline $\begin{array}{l}\text { Arsenic concentration } \\
(\mu \mathrm{g} / \mathrm{g})\end{array}$ & $\begin{array}{l}\text { Number of } \\
\text { respondents }\end{array}$ & Percentage \\
\hline$\leq 200$ & 45 & 11 \\
\hline$>200-500$ & 174 & 41 \\
\hline$>500-1000$ & 125 & 30 \\
\hline$>1000$ & 74 & 18 \\
\hline Total & 418 & 100 \\
\hline
\end{tabular}

\section{F. Body Mass Index of Sample Respondents}

In rural Bangladesh a major portion of people are underweight. The distribution of body mass index of the sample respondents are shown in Table 5. The nutritional status of the sample respondents were evaluated based on their body mass index. It was found that $212(51 \%)$ of the sample respondents were normal weight, while $180(43 \%)$ were underweight, $20(5 \%)$ were overweight and $6(1 \%)$ were obesity. It is therefore, highly likely that these sample respondents represent the broad characteristics of BMI of rural residents. Malnutrition is highly prevalent in rural Bangladesh [40].
TABLE 5: DISTRIBUTION OF BODY MASS INDEX OF THE RESPONDENTS

\begin{tabular}{|l|l|l|}
\hline Nutritional status & $\begin{array}{l}\text { Number of } \\
\text { respondents }\end{array}$ & Percentage \\
\hline Underweight $=<18.5$ & 180 & 43 \\
\hline Normal weight $=18.5-24.9$ & 212 & 51 \\
\hline Overweight $=25-29.9$ & 20 & 5 \\
\hline Obesity & 06 & 1 \\
\hline Total & 418 & 100 \\
\hline
\end{tabular}

\section{G. Association between BMI and Arsenic Concentration in} Urine

The join frequency distributions of arsenic concentration in the urine and body max index are presented in the Table 6 . As seen in the leftmost column of the body mass index, the proportion of under weight and arsenic concentration in urine is equal to or smaller than $200 \mu \mathrm{g} / \mathrm{L}$ was 7.78 percent only. On the other hand, other $92.22 \%$ underweight respondents contained more than $200 \mu \mathrm{g} / \mathrm{g}$ arsenic in urine while $36.67 \%$ contained from more than 200 to $500 \mu \mathrm{g} / \mathrm{g}, 34.44 \%$ contained from more than 500 to $1000 \mu \mathrm{g} / \mathrm{g}$ and $21.11 \%$ contained more than $1000 \mu \mathrm{g} / \mathrm{g}$. The cells in the second column is shown that around $13.68 \%$ normal weight respondents contained equal to or smaller than $200 \mu \mathrm{g} / \mathrm{g}$ arsenic and $86.32 \%$ respondents contained more than $200 \mu \mathrm{g} / \mathrm{g}$ arsenic in urine. While $44.81 \%$, $25.95 \%$ and $15.56 \%$ normal weight sample respondents contained from more than 200 to 500 , from more than 500 to 1000 and more than $1000 \mu \mathrm{g} / \mathrm{g}$ arsenic in urine, respectively. In the column three under body mass index, among the overweight sample respondents $10.04 \%, 50.00 \%, 30.13 \%$ and $10.04 \%$ contained equal to or smaller than 200 , more than 200 to 500 , more than 500 to 1000 and more than 1000 $\mu \mathrm{g} / \mathrm{g}$ arsenic in urine, respectively. Among the obesity $50.00 \%, 33.33 \%$ and $16.67 \%$ of the sample respondents contained more than 200 to 500, more than 500 to 1000 and more than $1000 \mu \mathrm{g} / \mathrm{g}$ arsenic in urine, respectively. In a recent study, an association between nutritional status and chronic exposure to arsenic has been reported among Bangladeshi patients [40].

TABLE 6: JOIN FREQUENCY DISTRIBUTION OF BMI AND ARSENIC CONCENTRATION IN URINE

\begin{tabular}{|l|l|l|l|l|l|}
\hline \multirow{2}{*}{$\begin{array}{l}\text { Arsenic in } \\
\text { urine }(\mu \mathrm{g} / \mathrm{L})\end{array}$} & \multicolumn{4}{|c|}{ Body mass index } & \multirow{2}{*}{ Total } \\
\cline { 2 - 5 } & Under weight & Normal weight & Overweight & Obesity & \\
\hline$\leq 200$ & $3.35(14)$ & $6.94(29)$ & $0.48(2)$ & $0.00(0)$ & $10.77(45)$ \\
\hline$>200-500$ & $15.79(66)$ & $22.73(95)$ & $2.39(10)$ & $0.72(3)$ & $41.63(174)$ \\
\hline$>500-1000$ & $14.83(62)$ & $13.16(55)$ & $1.44(6)$ & $0.48(2)$ & $29.90(125)$ \\
\hline$>1000$ & $9.09(38)$ & $7.89(33)$ & $0.48(2)$ & $0.24(1)$ & $17.70(74)$ \\
\hline Total & $43.06(180)$ & $50.72(212)$ & $4.78(20)$ & $1.44(6)$ & $100.00(418)$ \\
\hline
\end{tabular}

Number of sample respondents in the parentheses.

An epidemiological study conducted in West Bengal, India showed malnutrition correlated with increased prevalence of skin manifestations in arsenic exposed population [18]. The studies were reported that low socio-economic status and poor nutritional status of arsenicosis sufferers people in Taiwan and Chile [16], [17], [19], [41]. Lower BMI was reported among the arsenicosis patients compared to the unexposed population in a previous study in Bangladesh [40]. However, a study from Atacameño in northern Chile reported no evidence of malnutrition among individuals with arsenic induced skin lesions [42]. 


\section{CONCLUSION}

The findings described at the present study provide novel information on the urinary arsenic concentration in the highly arsenic contaminated area and a crucial picture of arsenic exposure and body mass index of rural residents as well as arsenic concentrations in drinking water. These results indicate that this population presented a high exposure level and clearly show the critical situation present in the study area, which would lead to increase the health burden, social discrimination and other problems. This study has successfully examined biomarker- arsenic in urine and arsenic concentration in drinking water and body mass index. Additional research is needed to further characterize the other biomarkers and health impact of arsenic exposure. The findings of the study are expected to be useful to take appropriate steps for mitigating the present arsenic crisis for rural livelihood pattern improvement as well as the overall improvement of Bangladesh.

\section{ACKNOWLEDGMENT}

The author would like to express his sincere gratitude to Dr. Kazumi Asako, Professor, Institute of Economic Research, Hitotsubashi University, Tokyo, Japan for his help and constant guidance. Author duly acknowledges his indebtedness to Dr. Akhtar, Dr. Islam, Dr. Imam and Dr. Ahmed for allowing him to use the data. Thanks also are Professor Asako seminar members for their comments on earlier draft.

\section{REFERENCES}

[1] R. Haque, D. N. Mazumder, S. Samanta, N. Ghosh, D. Kalman, M. M. Smith, et al., "Arsenic in drinking water and skin lesions: dose-response data from West Bengal, India," Epidemiology, vol. 14, 2003, pp. 174-182.

[2] A. H. Smith, M. Goycolea, R. Haque, M. L. Biggs, "Marked increase in bladder and lung cancer mortality in a region of northern Chile due to arsenic in drinking water," Am. J. Epidemiol., vol. 147, 1998, pp. 660-669.

[3] M. M. R. Sarker, "Determinants of Respondents' Perception and Social Implications of Arsenic Poisoning through Groundwater in Bangladesh," Int. J. Environ. Res. Public Health., vol. 7, 2010, pp. 3644-3656.

[4] M. G. Alam, G. Allison, F. Stagnitti, A. Tanaka, M. Westbrooke, "Arsenic contamination in Bangladesh groundwater: a major environmental and social disaster," Int. J. Environ. Health Res., vol. 12, 2002, pp. 235-253.

[5] National Research Council, Arsenic in Drinking Water 2001 Update. Washington, DC: National Academy Press. 2001.

[6] M. M. Hassan, P. J. Atkins, C. E. Dunn, "Social implications of arsenic poisoning in Bangladesh," Social Science \& Medicine, vol. 61, 2005, pp. 2201-2211.

[7] J. P. Buchet, R. Lauwerys, "Evaluation of exposure to inorganic arsenic in man," In Analytical Techniques for Heavy Metals in Biological Fluids; S. Facchetti, Ed. Amsterdam, The Netherland, Elsevier, 1983, pp. $75-90$.

[8] International Agency for Research on Cancer (IARC), Some Drinking-Water Disinfectants and Contaminants, Including Arsenic, IARC Monogr Eval Carcinog Risks Hum, 84, 2004.

[9] National Toxicology Program, Tenth Report on Carcinogens. Research Triangle Park, NC:National Toxicology Program, 2002.

[10] P. L. Smedley, D. G. Kinniburgh, "A review of the source, behaviour and distribution of arsenic in natural waters," Appl. Geochem., vol. 17, 2002, pp. 517-568

[11] L. M. Del Razo, G. G. Garcia-Vargas, H. Vargas, A. Albores, M. E. Gonsebatt, R. Montero, et al., "Altered profile of urinary arsenic metabolites in adults with chronic arsenicism: A pilot study," Arch. Toxicol., vol, 71, 1997, pp. 211-217.
[12] H. V. Aposhian, M. M. Aposhian, "Arsenic toxicology: five questions," Chem. Res. Toxicol., vol. 19, 2006, pp. 1-15.

[13] W. R. Cullen, K. J. Reimer, "Arsenic speciation in the environment," Chem. Rev., vol. 89, 1989, pp. 713-764.

[14] K. T. Kitchin, "Recent advances in arsenic carcinogenesis: Modes of action, animal model systems, and methylated arsenic metabolites," Toxicol. Appl. Pharmacol.,vol. 172, 2001, pp. 249-261.

[15] D. G. Kinniburgh, P. L. E. Smedley, Arsenic Contamination of Groundwater in Bangladesh. Dhaka, Bangladesh; British Geological Survey (BGS), Department for International Development (DFID), Government of the People's Republic of Bangladesh, Ministry of Local Government, Rural Development and Cooperatives, Department of Public Health Engineering (DPHE), 2001, p. 2.

[16] J. M. Borgono, P. Vicent, H. Venturino, A. Infante, "Arsenic in the drinking water of the city of Antofagasta: Epidemiological and clinical study before and after the installation of a treatment plant," Environ. Health Perspect., vol. 19, 1977, pp. 103-105.

[17] Y. M. Hsueh, G. S. Cheng, M. M. Wu, H. S. Yu, T. L. Kuo, C. J. Chen, "Multiple risk factors associated with arsenic-induced skin cancer: effects of chronic liver disease and malnutritional status," Br. J. Cancer, vol. 71, 1995, pp. 109-114.

[18] D. N. Mazumder, R. Haque, N. Ghosh, B. K. De, A. Santra, D. Chakraborty, A. H. Smith, "Arsenic levels in drinking water and the prevalence of skin lesions in West Bengal, India,” Int. J. Epidemiol., vol. 27, 1998, pp. 871-877.

[19] Tseng, W. P., "Effects and dose-response relationships of skin cancer and black foot disease with arsenic," Environ. Health. Perspect., vol. 19, 1977, pp. 109-119.

[20] A. H. Milton, S. M. Shahidullah, W. Smith, K. S. Hossain, Z. Hasan, K. T. Ahmed, "Association between Chronic Arsenic Exposure and Nutritional Status among the Women of Child Bearing Age: A Case-Control Study in Bangladesh," Int. J. Environ. Res. Public Health, vol 7, 2010, 2811-2821.

[21] M. M. R. Sarker, "Modeling of the Factors Influence on Arsenicosis Status, Averting Behavior and Willingness to Pay," Int. J. Ecol. Econ. Stat., vol. 21, Feb. 2011, pp. 99-106.

[22] Dhaka Community Hospital Trust, Arsenic Problem in Bangladesh, 2005, Available, http://www.dchtrust.org/arsenic_problem.htm [accessed November 20, 2010].

[23] A. Zaman, 2001, "Poison in the well. New Internationalist, 332, 16-17.

[24] G. H. Rabbani, M. Nasir, S. K. Saha, M. M. Islam, M. Alauddin, "Clinical and biochemical profiles of chronic arsenicosis patients in Bangladesh," in Bangladesh Environment, vol. 1, A. F. Ahmed, S. Tanveer, A. B. M. Badruzzaman, Ed. Dhaka, Bangladesh; BAPA, 2002, pp. 361-371.

[25] G. Alain, J. Tousignant, E. Rozenfarb, 1993, "Chronic arsenic toxicity," Int. J. Dermatol., vol. 32, pp.899-901.

[26] S. Yeh, "Skin cancer in chronic arsenicism," Hum. Pathol., vol. 4, 1973, 469-485.

[27] A. H. Milton, M. Rahman, "Respiratory effects and arsenic contaminated well water in Bangladesh," Int. J. Environ. Health Res., vol. 12, 2002, pp. 175-179.

[28] World Health Organization (WHO), Environmental Health Criteria 18, Arsenic. International Programme on Chemical Safety. Geneva, Switzerland, 1981, pp. 27-30.

[29] I. Thornton, M. Farago, "The geochemistry of arsenic," in Arsenic: Exposure and Health Effects, R. L. Calderon, W. R. Chappell, C. O. Abernathy, Ed. London, Chapman \& Hall, 1997, pp. 1-16.

[30] BBS and UNICEF. Bangladesh Multiple Indicator Cluster Survey Progotir Pathey 2009. BBS-UNICEF, Dhaka: Bangladesh Bureau of Statistics, 2010.

[31] Bangladesh Arsenic Mitigation Water Supply Project (BAMWASP), 2006. Available: http://www.bamwsp.org.

[32] J. Josephson, "The slow poisoning of Bangladesh: metals in drinking water," Environ. Health Perspect., vol. 110, 2002, pp. 690-691.

[33] F. Parvez, Y. Chen, M. Argos, A. Z. Hussain, H. Momotaj, R. Dhar, A. van Green, H. J. Graziano, H. Ahsan, “ Prevalence of arsenic exposure from drinking water and awareness of its health risks in a Bangladeshi population: results from a large population-based study," Environ. Health Perspect., vol. 114, 2006, pp. 355-359.

[34] BGS (British Geological Survey) Arsenic Contamination in Groundwater in Bangladesh-Phase 1, vol 1, Summary, D. G. Kinniburgh, P. L. Smedly, Ed. 2001. Available: http://www.bgs.ac.uk/ [accessed November 20, 2010]

[35] U. K. Chowdhury, B. K. Biswas, T. R. Chowdhury, G. Samanta, B. K. Mandal, G. C. Basu, C. R. Chanda, D. Lodh, K. C. Saha, S. K. Mukherjee, S. Roy, S. Kabir, Q. Ouamruzzaman, D. Chakaborti, 
"Groundwater arsenic contamination in Bangladesh and West Bengal, India,” Environ. Health Perspect., vol. 108, 2000, pp. 393-397.

[36] BGS (British Geological Survey), Groundwater Studies for Arsenic Contamination in Bangladesh-Phase 1 Findings, 1998. Available: http://www.bgs.ac.uk/arsenic/bphase1/B_find.htm [accessed November 20, 2010].

[37] M. Maharjan, C. Watanabe, Sk. A. Ahmed, R. Ohtsuka, "Arsenic contamination in drinking water and skin manifestation in low land Nepal: The first community based survey," Am. J. Trop. Med. Hyg., vol. 73, 2005, pp. 477-479.

[38] J. A. Navoni, M. Calatayud, N. M. Olivera, J. A. Tschambler, C. Gimenzer, G. S. Paredes, S. S. Farias, D. Velez, M. M. G. Bovi and E. C. Villaamil, "Urinary arsenic content of Argentinean child population environmentally exposed by drinking water," 2nd International Congress, Arsenic in the environment; Arsenic from nature to humans. Valencia, 21-23 May, 2008, p. 491.

[39] L. N. Islam, A. H. M. N. Nabi, M. M. Rahman, M. A. Khan, A. I. Kazi, "Association of Clinical Complications with Nutritional Status and the Prevalence of Leukopenia among Arsenic Patients in Bangladesh," Int. J. Environ. Res. Public Health, vol. 1, 2004, pp.74-82.

[40] A. H. Milton, Z. Hasan, S. M. Shahidullah, S. Sharmin, M. D. Jakariya, , M. Rahman, K. Dear, W. Smith, "Association between nutritional status and arsenicosis due to chronic arsenic exposure in Bangladesh,” Int. J. Environ. Health Res., vol. 14, 2004, pp. 99-108.

[41] R. Zaldivar, "Ecological investigations on arsenic dietary intake and endemic chronic poisoning in man: Dose-response curve," Zentralbl Bakteriol [Orig B], vol. 164, 1977, pp. 481-484.

[42] A. H. Smith, A. P. Arroyo, D. N. Mazumder, M. J. Kosnett, A. L. Hernandez, M. Beeris, M. M. Smith, L. E. Moore, "Arsenic-induced skin lesions among Atacameno people in Northern Chile despite good nutrition and centuries of exposure," Environ. Health Perspect., 108, 617-620. 